DOI: 10.14807/ijmp.v10i4.758

\title{
ANALYSIS OF THE DATA ON THE QUALITY EXPECTATION IN SCHOOL SERVICES, FROM THE STUDENT'S PERCEPTION
}

\author{
Paulo Cesar Chagas Rodrigues \\ Instituto Federal de Educação, Ciência e Tecnologia de São \\ Paulo (IFSP), Brazil \\ E-mail: paulo.rodrigues@ifsp.edu.br \\ Eddaniella Moraes Silva Fernandes \\ Instituto Federal de Educação, Ciência e Tecnologia de São \\ Paulo (IFSP), Brazil \\ E-mail: eddaniella_moraes@hotmail.com \\ Franco da Silveira \\ Universidade Federal do Rio Grande do Sul, Brazil \\ E-mail: franco.da.silveira@hotmail.com \\ Bruno Miranda dos Santos \\ Universidade Federal do Rio Grande do Sul, Brazil \\ E-mail: brmiranda10@gmail.com \\ Filipe Molinar \\ Universidade Regional Integrada do Alto Uruguai e Missões \\ (URI), Brazil \\ E-mail: fmacmec@gmail.com \\ Submission: 01/10/2019 \\ Accept: 02/11/2019
}

\section{ABSTRACT}

The improvement of educational services can have a direct impact on the student's avoidance rate in the concomitant / subsequent technical courses. Being of vital importance to be able to anticipate and anticipate the factors that are important in the provision of educational services aiming at satisfying the student's satisfaction. The purpose of this study is to apply a questionnaire that allows to evaluate the perception or expectation of the students who are already attending and those who are beginning their study day in the concomitant / subsequent technical courses in Administration. It will become the basis for future studies as to the main quality factors in service that affect student satisfaction and loyalty. For this purpose, the SERVQUAL tool will be used to measure the quality of the services provided. 
DOI: 10.14807/ijmp.v10i4.758

Keywords: ServQual; Quality; Education; Technician; Administration

\section{INTRODUCTION}

Organizational success is related to the profile of the administrative leaders who have the competencies to lead the concurrent demands of the competitors (SMITH; TRACEY, 2016). Their decisions are crucial and they become an effective competitive strategy for the company (ROSS; SHARAPOV, 2015). Thus, the incessant search for the guarantee of excellence in the provision of services and the competitiveness in the global market are directly linked to the improvement in quality. Longo and Vergueiro (2003) corroborate that Quality Management aims at the survival of organizations through consumer satisfaction.

As a way of studying the internal factors that contribute to the fulfillment of consumers' expectations, whether they are students of the integrated technical course, concomitant or subsequent in administration, or other courses, the SERVQUAL quality tool was used. According to research by Dettmer, Socorro and Katon (2002) and Rosemberg et al. (2018), SERVQUAL allows structuring quality factors in five dimensions: tangibility, reliability, responsiveness, security and empathy. These factors may contribute to the identification of problems in the educational processes of the institution as a whole.

Wagner et al. (2017) corroborate that the service sector has been important in the world economy, including in academic sectors, as mentioned by Loures and Camponar (2005), this importance has been reflected in the academic area since the 1960s, when the marketing researchers began to demonstrate the differences between goods and services, but it was only during the 1980s that we began to study the subject more deeply.

Cukier and Silva (2012) complement that the quality of service from the SERVQUAL tool should be measured from the gap between the expectation and the quality perceived by the consumer, be they students, teachers or employees, and the research should be compared in three different moments: before, during and after the service.

In this context, paper aims to identify which attributes of quality perception are most important for the student consumer, to know if there is a predominance of one group in relation to the other. Finally, through a data analysis, we intend to verify if the 
grouping of factors follows a logic of technical information to support strategies in the educational context.

The study assumes relevance due to the need that the educational organizations present in the adoption of strategies, in face of the current market evolutions, that interfere in order to achieve a symmetry in the company administration and in the analysis of educational public policies.

The paper was structured in different sections. In section 2 the research method is outlined, highlighting a flow chart that bases the steps of data collection, analysis and interpretation obtained and its main aspects. Subsequently, the bibliographic review is contextualized presenting the main contributions of research relevant to the area under study in this article. In the sequence, the results are shown. Finally, the conclusions of the research and their respective references are presented.

\section{METHOD OF RESEARCH}

This section aims to present pertinent aspects to the methodological procedures adopted to carry out this work. From the central concept formulated as a general objective, the methodology was established for each stage of the study. In order to define the survey phase, two macrocategories were determined for the data collection: (i) determination of the search tool "SERVQUAL": (ii) structuring the gaps that make up the students' perception of quality.

From the flow shown in Figure 1 and Figure 2, the steps that were necessary for the practical realization of the research are sequentially observed. The initial stage was the formulation of the research problem and its delimitation, where an interface between the educational area and quality. Next, the general and specific objectives of this work were elaborated. In the third stage, the theoretical study was made. 
DOI: 10.14807/ijmp.v10i4.758

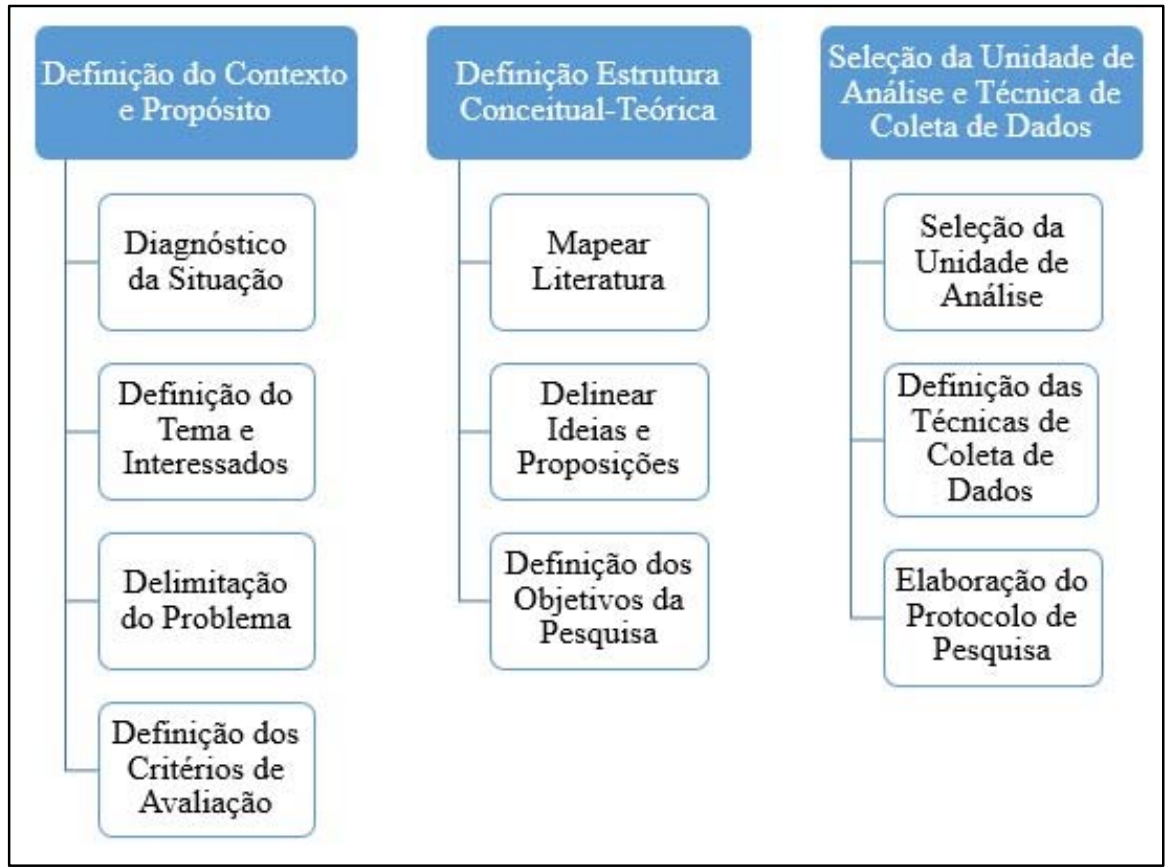

Figure 1: Activities carried out to conduct the action research Source: Authors (2017)

In the fourth stage, through the theoretical study, we determined the general framework of questions to be listed in the SERVQUAL tool. In the fifth step, the operators were selected to compose the factor guidelines. In the sixth step, the theoretical factors were elaborated, in tabular form, through the selected indicators. In the seventh stage, the factors were discussed and the need for textual description was verified.

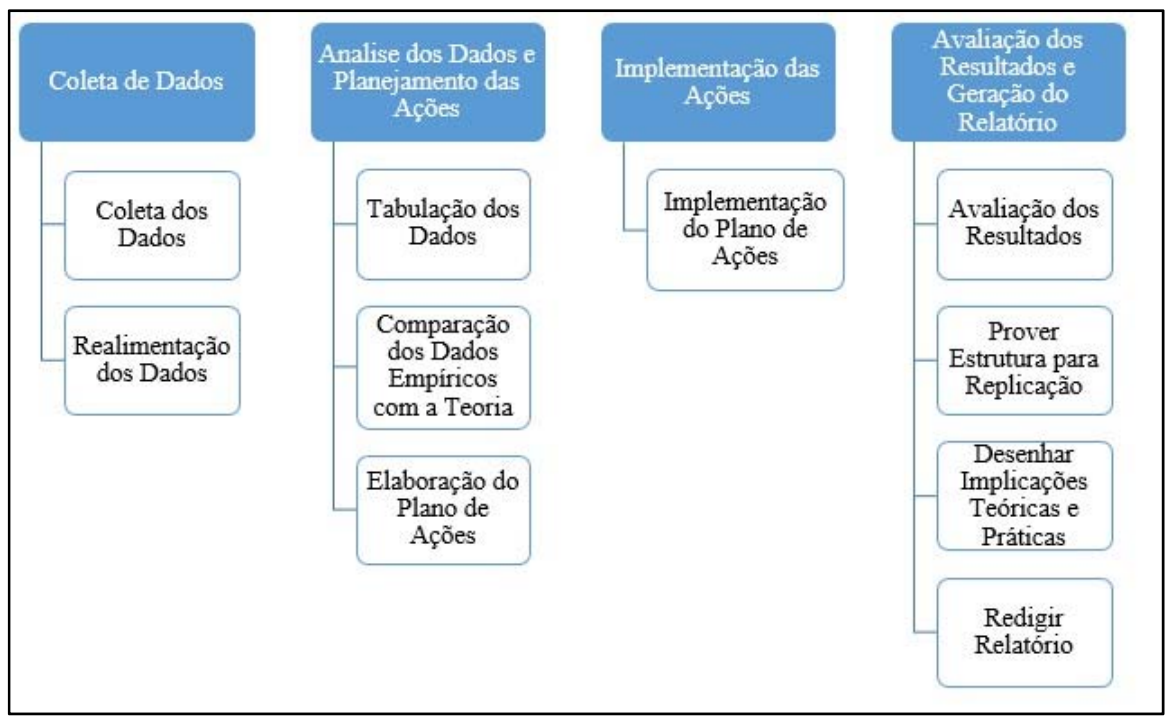

Figure 2: Key steps activities for conducting action research Source: Authors (2017)

The public in study is represented by the students of the concomitant/ subsequent technical courses in administration, logistics and interior design. As for the 
data collection period, because it is a cross-sectional study, it was applied to the students who attend the institution in the afternoon and evening period and who are already studying or are beginning their studies.

The data collection was performed based on a questionnaire applied in the course and the results obtained in this research underwent a process of analysis. In order to keep the students confidential, they were not identified in the present study. The questions in the questionnaire were related to procedures of quality dimensions, such as tangibility, reliability, responsiveness, safety and empathy. The procedures used to analyze the information were: coding of the answers, tabulation of data and interpretation of the particularities. MS Excel was used for data tabulation.

According to Araujo et al. (2017), the SERVQUAL tool is a model of ordering, increasingly, notes that are obtained, aiming at measuring the strengths and weaknesses of quality in consideration of five dimensions: tangibility, reliability, responsiveness, security and empathy. Table 1 presents the questions used in the institution.

Table 1: Description of constructor dimensions

\begin{tabular}{|c|c|c|}
\hline Constructor & & Dimensions \\
\hline \multirow{4}{*}{ Tangibles } & Q1 & - Modern equipment \\
\hline & Q2 & - Visually attractive physical facilities \\
\hline & Q3 & $\cdot$ - Clean and well-dressed staff \\
\hline & Q4 & - Visually attractive service equipment and materials \\
\hline \multirow{3}{*}{ Reliability } & Q5 & - Show real interest in solving the problem \\
\hline & Q6 & - Non-discriminatory treatment provided by employees \\
\hline & Q7 & - Perform the service in the promised time \\
\hline \multirow{3}{*}{ Responsiveness } & Q8 & - Reliably save service history \\
\hline & Q9 & - First time customer problem solving \\
\hline & Q10 & - Inform about the period of execution of the services \\
\hline \multirow{3}{*}{ Warranty } & Q11 & - High quality service standards \\
\hline & Q12 & - High quality administrative services \\
\hline & Q13 & - High-quality academic services \\
\hline \multirow{3}{*}{ Empathy } & Q14 & - Student friendly service \\
\hline & Q15 & - Provides easy-to-understand information \\
\hline & Q16 & - Convenient operating hours \\
\hline
\end{tabular}

Source: Adaptado de Parasuraman, Zeithaml e Berry (1988), Cukier e Silva (2012) e Leonard (2018)

The questionnaire was applied through the use of the Google Drive platform, which consists of the concept of cloud computing, facilitating the storage of files and the formulation of questionnaires using the internet as a means of relation to apply them in companies. The data obtained, together with the students, were used as a basis to characterize the process of development of school management for the 
teachers participating in the research. Finally, the general structuring of the research is classified as descriptive and comparative, of an exploratory nature.

Based on the analyzes of the researches and their respective authors, as well as the research reference made by Leonard (2018), the following research hypotheses were developed:

- Research hypothesis 1 (H1): Perception of tangible dimension has a positive relation on general perceptions of quality of service in relation to educational services;

- Research hypothesis $2(\mathrm{H} 2)$ : Perception of the reliability dimension has a positive relation in the general perception of service quality in relation to educational services;

- Research hypothesis $3(\mathrm{H} 3)$ : The perception of the responsiveness dimension has a positive relation in the general perceptions of service quality in relation to educational services;

- Research hypothesis $4(\mathrm{H} 4)$ : Perception of guarantee dimension has a positive relation on general perceptions of quality of service in relation to educational services;

- Research hypothesis 5 (H5): The perception of empathy has a positive relation in general perceptions of quality of service in relation to educational services.

As for sampling, Gil (2002) points out that in social surveys, different forms can be assumed, depending on the type of population, its extent and the material conditions for carrying out the research. In this sense, the sample is not accidental probabilistic, since the elements of the population are referring to the students who attend the concurrent / subsequent technical courses afternoon and evening and daily.

In this direction, Cukier and Silva (2012) treat SERVQUAL as a multi-item scale constructed to measure expectations $(E)$ and/or perceptions $(P)$ of the learning consumers according to the service provided. Quality $(Q)$ is the result of the difference between $(P)$ and $(E)$.

The evaluation of quality satisfaction is done by subtracting perceived performance $(P)$ from expectations $(E)$. After this step the scores found in perceptions and expectations are calculated, and three responses can be obtained: 
- 1st point: Unmet expectation (Expectation> Perception). It occurs when the consumer creates a high expectation and this is not satisfied;

- 2nd point: Expected attention (Perception> Expectation). It occurs when the consumer realizes that his expectation has been met;

- 3rd point: Expectation surpassed (Perception >> Expectation). It occurs when the perception of the benefits acquired by the consumer surpasses all the competitive value propositions, having high engagement.

\section{SERVQUAL APPROACH TO MEASURE THE QUALITY OF EDUCATIONAL SERVICES}

In the bibliographic review the concepts that relate to the objective of the work are demonstrated. Firstly, it is a succinct vision referring to the SERVQUAL approach, then a brief description of the five dimensions, highlighting its main peculiarities. Finally, the contextualization of the main themes of the new technological revolution.

According to Clewes (2003) and Marzo-Navarro, Pedraja-Iglesias and Pilar Rivera-Torres (2005), there is no agreement on the best model to measure the quality of the educational service. Each model used has its own advantages and disadvantages. In general, the models most used to measure the quality of service in educational services are SERVQUAL (PARASURAMAN; ZEITHAML; BERRY, 1988), SERVPERF (ABDULLAH, 2006b), HEdPERF (ABDULLAH, 2006a) and Wagner et al. (2017).

According to Parasuraman, Zeithaml and Berry (1988), the core of this model is the ability to measure whether the actual performance of services exceeds consumer expectations. To measure this, five dimensional measures are used:

a) Tangibles: are related to the physical condition and availability of facilities and human resources;

b) Reliability: it is related to the capacity of service providers to provide services as promised;

c) Responsiveness: is related to the ability of service providers to provide the best service to consumers;

d) Guarantee: deals with the knowledge and skills of the employees of the service providers; 
ISSN: 2236-269X

DOI: 10.14807/ijmp.v10i4.758

e) Empathy: deals with the personal care provided by the service provider to customers / consumers.

The use of SERVQUAL in educational services has been the focus of new studies on student and teacher behavior (ZAMMUTO; KEAVENEY; O'CONNOR, 1996; BROWNE et al., 1998; OLDFIELD; BARON, 2000; DE JAGER; GBADAMOSI, 2013; WAGNER et al., 2017).

\section{RESULTS}

The analysis of the results was performed based on the attributes related to the quality of the service, always with the objective of finding the elements responsible for the quality of service and customer satisfaction. Subsequently, a classificatory analysis will be carried out of the dimensions that were better evaluated by the students and which need to focus on improving satisfaction.

Table 2 presents the questions, as well as the value that each student gave for each item, in which 1 means unimportant and 5 very important. It also shows the total amount that each question received.

Table 2: Description of the questions and their respective values

\begin{tabular}{|c|c|c|c|c|c|c|c|c|c|c|c|c|c|c|c|c|c|c|c|c|c|c|c|c|c|c|c|c|}
\hline & & & $u d t$ & nt & res & por & $d e$ & & & & & & & & & & & & & & & & & & & & & \\
\hline Seq & Description & 1 & 2 & 3 & 4 & 5 & 6 & 7 & 8 & 9 & $\begin{array}{l}1 \\
0\end{array}$ & $\begin{array}{l}1 \\
1\end{array}$ & $\begin{array}{l}1 \\
2 \\
\end{array}$ & \begin{tabular}{|l}
1 \\
3 \\
\end{tabular} & $\begin{array}{l}1 \\
4 \\
\end{array}$ & \begin{tabular}{|l|}
1 \\
5 \\
\end{tabular} & $\begin{array}{l}1 \\
6 \\
\end{array}$ & $\begin{array}{l}1 \\
7 \\
\end{array}$ & $\begin{array}{l}1 \\
8 \\
\end{array}$ & \begin{tabular}{|l}
1 \\
9 \\
\end{tabular} & $\begin{array}{l}2 \\
0\end{array}$ & $\begin{array}{l}2 \\
1 \\
\end{array}$ & $\begin{array}{l}2 \\
2 \\
\end{array}$ & \begin{tabular}{|l}
2 \\
3 \\
\end{tabular} & \begin{tabular}{|l|}
2 \\
4 \\
\end{tabular} & $\begin{array}{l}2 \\
5 \\
\end{array}$ & \begin{tabular}{|l}
2 \\
6 \\
\end{tabular} & ర్త్ \\
\hline 1 & $\begin{array}{l}\text { Modern } \\
\text { equipment }\end{array}$ & 4 & 3 & 5 & 5 & 5 & 3 & 5 & 5 & 3 & 4 & 5 & 4 & 5 & 3 & 4 & 5 & 4 & 4 & 5 & 5 & 5 & 4 & 5 & 4 & 5 & 5 & $\underset{\nabla}{\Psi}$ \\
\hline 2 & $\begin{array}{l}\text { Visually } \\
\text { appealing } \\
\text { physical } \\
\text { facilities } \\
\end{array}$ & 4 & 4 & 5 & 5 & 4 & 5 & 5 & 5 & 4 & - & 5 & 3 & 3 & 2 & 2 & 3 & 3 & 3 & 2 & 5 & 5 & 4 & 5 & 3 & 4 & - & ח \\
\hline 3 & $\begin{array}{l}\text { Clean and } \\
\text { well-dressed } \\
\text { staff }\end{array}$ & 5 & 5 & 5 & 5 & 5 & 4 & 5 & 5 & 3 & 5 & 5 & 5 & 5 & 3 & 3 & 3 & 3 & 4 & 5 & 5 & 5 & 5 & 5 & 5 & 5 & 1 & $\underset{⿱}{\mathbf{S}}$ \\
\hline 4 & $\begin{array}{l}\text { Visually } \\
\text { appealing } \\
\text { service } \\
\text { equipment } \\
\text { and } \\
\text { materials }\end{array}$ & 5 & 4 & 5 & 5 & 5 & 3 & 5 & 5 & 4 & 4 & 5 & 3 & 3 & 4 & 3 & 2 & 4 & 4 & 4 & 5 & 5 & 5 & 5 & 4 & 5 & - & ஜ \\
\hline 5 & $\begin{array}{l}\text { Show real } \\
\text { interest in } \\
\text { resolving the } \\
\text { problem }\end{array}$ & 5 & 5 & 5 & 5 & 5 & 5 & 5 & 5 & 4 & 5 & 4 & 5 & 5 & 4 & 5 & 4 & 5 & 5 & 5 & 5 & 5 & 3 & 5 & 5 & 5 & - & $\stackrel{\circ}{ }$ \\
\hline 6 & $\begin{array}{l}\text { Non- } \\
\text { discriminator } \\
\text { y treatment } \\
\text { provided by } \\
\text { employees }\end{array}$ & 5 & 5 & 5 & 5 & 5 & 4 & 5 & 5 & 5 & 3 & 5 & 5 & 5 & 5 & 5 & 4 & 2 & 5 & 3 & 5 & 5 & 2 & 5 & 4 & 5 & - & 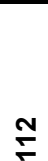 \\
\hline 7 & $\begin{array}{l}\text { Carry out the } \\
\text { service in the } \\
\text { promised } \\
\text { time }\end{array}$ & 4 & 5 & 5 & 5 & 5 & 3 & 5 & 5 & 4 & 4 & 4 & 4 & 3 & 4 & 5 & 5 & 5 & 4 & 4 & 4 & 5 & 4 & 4 & 5 & 5 & - & 을 \\
\hline
\end{tabular}


ISSN: 2236-269X

DOI: 10.14807/ijmp.v10i4.758

\begin{tabular}{|c|c|c|c|c|c|c|c|c|c|c|c|c|c|c|c|c|c|c|c|c|c|c|c|c|c|c|c|c|}
\hline 8 & $\begin{array}{l}\text { Save service } \\
\text { history } \\
\text { reliably }\end{array}$ & 5 & 5 & 5 & 5 & 5 & 4 & 5 & 5 & 5 & 5 & 4 & 5 & 5 & 5 & 5 & 5 & 3 & 4 & 5 & 5 & 5 & 5 & 4 & 4 & 3 & - & $\stackrel{0}{=}$ \\
\hline 9 & $\begin{array}{l}\text { Solving the } \\
\text { Customer } \\
\text { Problem the } \\
\text { First Time }\end{array}$ & 4 & 4 & 5 & 5 & 5 & 4 & 5 & 5 & 5 & 4 & 5 & 3 & 3 & 4 & 4 & 3 & 2 & 5 & 3 & 5 & 5 & 2 & 5 & 4 & 4 & 5 & $\stackrel{\infty}{\circ}$ \\
\hline 10 & $\begin{array}{l}\text { Inform about } \\
\text { the period of } \\
\text { execution of } \\
\text { the services }\end{array}$ & 4 & 4 & 5 & 5 & 5 & 3 & 5 & 5 & 4 & 4 & 4 & 4 & 3 & 4 & 5 & 5 & 4 & 4 & 5 & 5 & 5 & 3 & 4 & 5 & 5 & 2 & $\underset{F}{F}$ \\
\hline 11 & $\begin{array}{l}\text { High quality } \\
\text { service } \\
\text { standards } \\
\end{array}$ & 4 & 4 & 5 & 5 & 4 & 4 & 5 & 5 & 4 & 5 & 5 & 4 & 5 & 5 & 5 & 4 & 2 & 4 & 5 & 4 & 5 & 5 & 4 & 5 & 5 & 5 & $\stackrel{F}{F}$ \\
\hline 12 & $\begin{array}{l}\text { High-quality } \\
\text { administrativ } \\
\text { e services }\end{array}$ & 5 & 5 & 5 & 5 & 5 & 5 & 5 & 5 & 5 & 4 & 4 & 5 & 5 & 5 & 5 & 5 & 3 & 3 & 5 & 5 & 5 & 5 & 4 & 5 & 5 & 5 & $\stackrel{m}{N}$ \\
\hline 13 & $\begin{array}{l}\text { High-quality } \\
\text { academic } \\
\text { services }\end{array}$ & 4 & 5 & 5 & 5 & - & 4 & 5 & 5 & 5 & 4 & 5 & 5 & 4 & 4 & 5 & 4 & 3 & 3 & 4 & 4 & 5 & 4 & 5 & 4 & 4 & 5 & 욷 \\
\hline 14 & $\begin{array}{l}\text { Student } \\
\text { friendly } \\
\text { service }\end{array}$ & 4 & 5 & 5 & 5 & 5 & 5 & 5 & 5 & 4 & 5 & 5 & 5 & 5 & 5 & 4 & 5 & 3 & 5 & 5 & 4 & 5 & 2 & 5 & 5 & 5 & 2 & $\stackrel{\infty}{=}$ \\
\hline 15 & $\begin{array}{l}\text { Provides } \\
\text { easy-to- } \\
\text { understand } \\
\text { information }\end{array}$ & 3 & 5 & 5 & 5 & 3 & 4 & 5 & 5 & 4 & 5 & 5 & 4 & 5 & 3 & 4 & 5 & 4 & 3 & 5 & 4 & 4 & 5 & 4 & 5 & 4 & 5 & $\stackrel{m}{F}$ \\
\hline 16 & $\begin{array}{l}\text { Convenient } \\
\text { operating } \\
\text { hours }\end{array}$ & 4 & 5 & 5 & 5 & 5 & 3 & 5 & 5 & 4 & 5 & 5 & 3 & 5 & 5 & 4 & 5 & 2 & 4 & 5 & 5 & 5 & 5 & 4 & 4 & 5 & 5 & $\approx$ \\
\hline 17 & $\begin{array}{l}\text { would talk } \\
\text { about the } \\
\text { quality of the } \\
\text { institution to } \\
\text { the public } \\
\end{array}$ & 4 & 5 & 5 & 5 & 5 & 5 & 5 & 5 & 5 & 5 & 5 & 4 & 5 & 5 & 5 & 4 & 2 & 4 & 5 & 5 & 5 & 4 & 5 & 2 & 5 & 5 & $\stackrel{\mathscr{g}}{\leftarrow}$ \\
\hline 18 & $\begin{array}{l}\text { l would } \\
\text { recommend } \\
\text { the } \\
\text { institution to } \\
\text { the public }\end{array}$ & 5 & 5 & 5 & 5 & 5 & 5 & 5 & 5 & 5 & 5 & 5 & 5 & 5 & 5 & 5 & 5 & 5 & 4 & 5 & 5 & 5 & 4 & 5 & 5 & 5 & 5 & $\stackrel{\infty}{\sim}$ \\
\hline 19 & $\begin{array}{l}\text { will remain } \\
\text { faithful to this } \\
\text { institution } \\
\text { until my } \\
\text { studies are } \\
\text { completed, } \\
\text { as well as for } \\
\text { my studies in } \\
\text { the future }\end{array}$ & 4 & 5 & 5 & 5 & 5 & 5 & 5 & 5 & 5 & 5 & 5 & 4 & 5 & 4 & 5 & 5 & 5 & 5 & 5 & 5 & 5 & 3 & 5 & 5 & 5 & 5 & 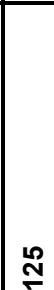 \\
\hline
\end{tabular}

From Table 2, the best evaluated item was item "18" and the worst evaluated was item "2". Regarding item 2, it is emphasized that it is a very subjective factor if we analyze under the prism of the student, because each one forms a perception of the physical facilities based on their experience. However, actions such as the renewal of physical structures can contribute to reduce this negative perception. Regarding item 18, an extremely positive convergence was observed in the direction of a free marketing of the institution, since the students themselves would recommend to the public. 
ISSN: 2236-269X

DOI: 10.14807/ijmp.v10i4.758

Table 3 shows the percentage values, based on the maximum value that each question obtained and the maximum overall value, being the sum of all the maximum values computed.

Table 3: Percentage values of each question

\begin{tabular}{|l|l|l|l|}
\hline Seq & Description & Line (\%) & $\begin{array}{l}\text { Genera } \\
\text { I(\%) }\end{array}$ \\
\hline $\mathbf{1}$ & Modern equipment & 87,6923 & 5,2462 \\
\hline $\mathbf{2}$ & Visually appealing physical facilities & 71,5385 & 4,2798 \\
\hline $\mathbf{3}$ & Clean and well-dressed staff & 87,6923 & 5,2462 \\
\hline $\mathbf{4}$ & Visually appealing service equipment and materials & 81,5385 & 4,8780 \\
\hline $\mathbf{5}$ & Show real interest in resolving the problem & 91,5385 & 5,4763 \\
\hline $\mathbf{6}$ & Non-discriminatory treatment provided by employees & 86,1538 & 5,1542 \\
\hline $\mathbf{7}$ & Carry out the service in the promised time & 84,6154 & 5,0621 \\
\hline $\mathbf{8}$ & Save service history reliably & 89,2308 & 5,3382 \\
\hline $\mathbf{9}$ & Solving the Customer Problem the First Time & 83,0769 & 4,9701 \\
\hline $\mathbf{1 0}$ & Inform about the period of execution of the services & 85,3846 & 5,1081 \\
\hline $\mathbf{1 1}$ & High quality service standards & 90,0000 & 5,3843 \\
\hline $\mathbf{1 2}$ & High-quality administrative services & 94,6154 & 5,6604 \\
\hline $\mathbf{1 3}$ & High-quality academic services & 84,6154 & 5,0621 \\
\hline $\mathbf{1 4}$ & Student friendly service & 90,7692 & 5,4303 \\
\hline $\mathbf{1 5}$ & Provides easy-to-understand information & 86,9231 & 5,2002 \\
\hline $\mathbf{1 6}$ & Convenient operating hours & 90,0000 & 5,3843 \\
\hline $\mathbf{1 7}$ & I would talk about the quality of the institution to the public & 91,5385 & 5,4763 \\
\hline $\mathbf{1 8}$ & I would recommend the institution to the public & 98,4615 & 5,8905 \\
\hline $\mathbf{1 9}$ & $\begin{array}{l}\text { I will remain faithful to this institution until the completion of my studies, } \\
\text { as well as for my future studies }\end{array}$ & 96,1538 & 5,7524 \\
\hline
\end{tabular}

Table 4 shows the distribution of the points between the 5 dimensions of the survey, in which the total value of the distribution should be the maximum value of 100 points. The red markings mean the size with the least importance, the yellow mark means the dimension with the second most important and the mark in green means the most important dimension.

Table 4: distribution of points between dimensions

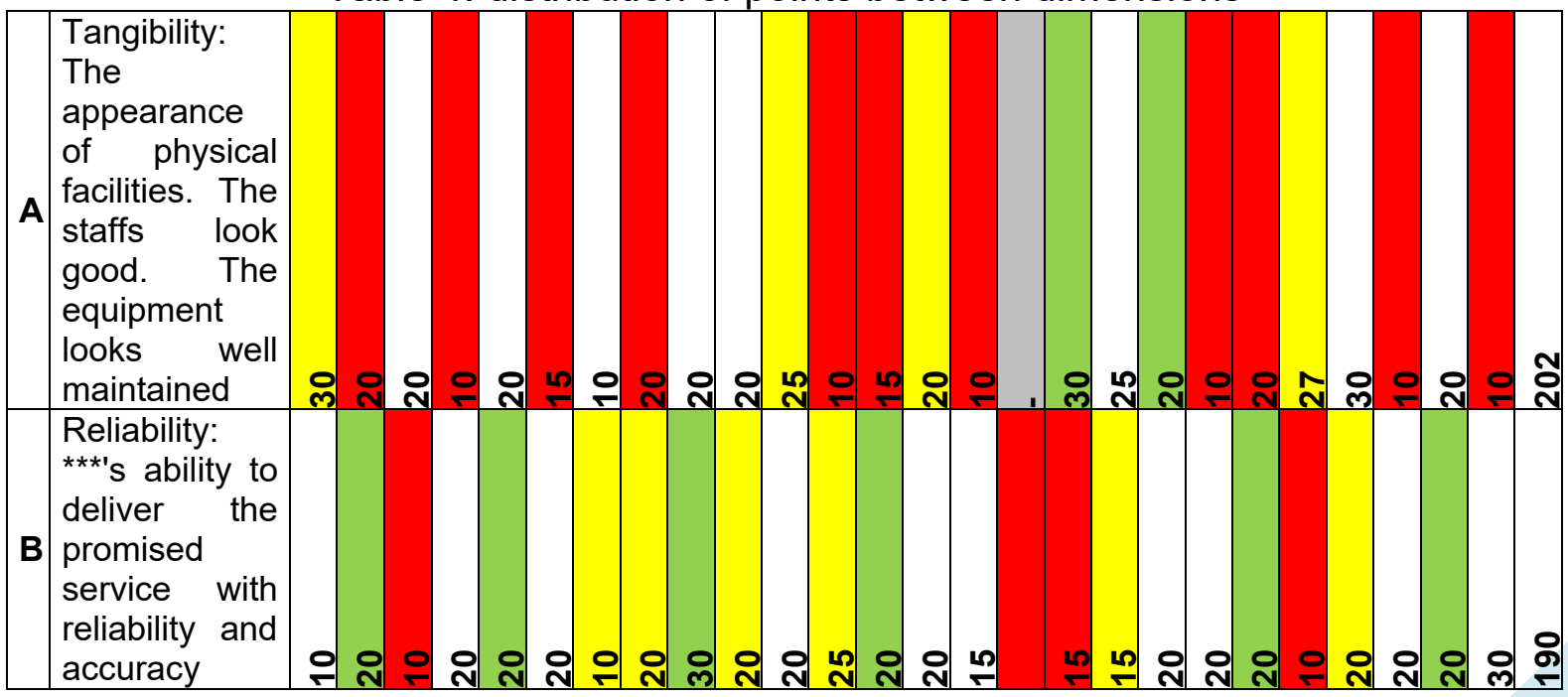


ISSN: 2236-269X

DOI: 10.14807/ijmp.v10i4.758

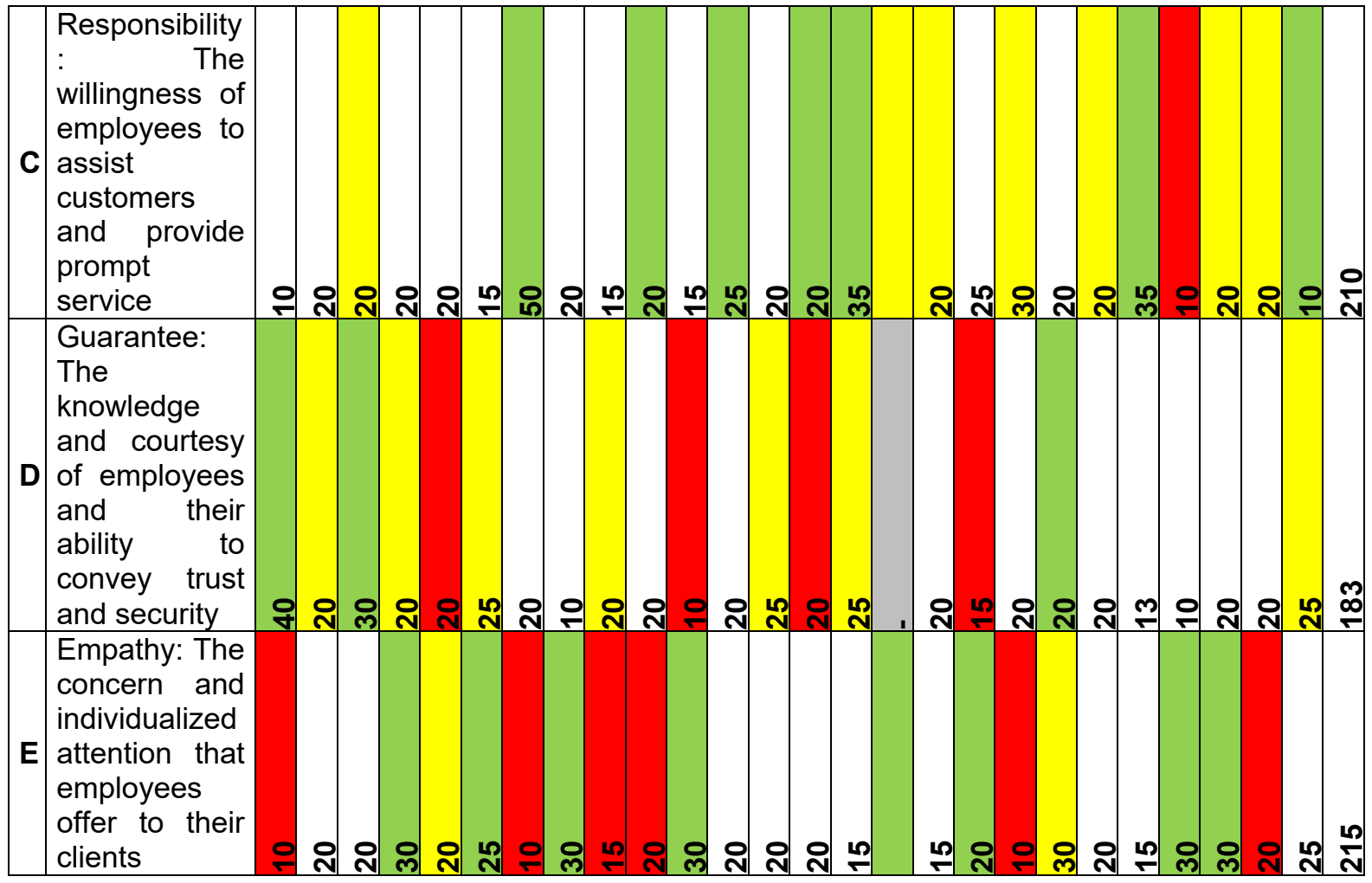

It is observed that the dimension "Empathy" was the best evaluated. The "Responsibility and Guarantee" dimensions were considered second, and the dimension "Tangibility" was considered the least important.

Table 5 shows the distribution of dimensions, in which item 1 means the most important, 2 the second most important and 3 the least important, as well as the general distribution, by sex and the embranco.

Table 5: cross-distribution between dimension and importance

\begin{tabular}{|l|l|l|l|l|l|l|l|l|l|l|l|l|}
\hline \multicolumn{3}{|l|}{ Occurrences } & \multicolumn{4}{l|}{ Male } & \multicolumn{3}{l|}{ Female } & \multicolumn{3}{l|}{ White } \\
\hline & $\mathbf{1}$ & $\mathbf{2}$ & $\mathbf{3}$ & $\mathbf{1}$ & $\mathbf{2}$ & $\mathbf{3}$ & $\mathbf{1}$ & $\mathbf{2}$ & $\mathbf{3}$ & $\mathbf{1}$ & $\mathbf{2}$ & $\mathbf{3}$ \\
\hline A & 2 & 4 & 11 & 1 & 1 & 0 & 1 & 2 & 10 & 0 & 1 & 1 \\
\hline B & 6 & 6 & 5 & 1 & 1 & 3 & 4 & 2 & 2 & 1 & 3 & 0 \\
\hline C & 7 & 7 & 1 & 0 & 3 & 0 & 4 & 4 & 1 & 3 & 0 & 0 \\
\hline D & 3 & 7 & 4 & 1 & 0 & 1 & 2 & 6 & 2 & 0 & 1 & 1 \\
\hline E & 8 & 2 & 5 & 2 & 0 & 1 & 5 & 2 & 1 & 1 & 0 & 3 \\
\hline
\end{tabular}

In this Table 5, the "Tangibility" dimension was considered by two students as the most important and by four students as the second most important and by eleven students as the least important. The "Reliability" dimension, however, remained within an average of distribution, in which six students answered that it was the most important or the second most important and five students answered that it is the least important. 
INDEPENDENT JOURNAL OF MANAGEMENT \& PRODUCTION (IJM\&P)

http://www.ijmp.jor.br

v. 10, n. 4, Special Edition IFLOG 2018

ISSN: 2236-269X

DOI: 10.14807/ijmp.v10i4.758

The Dimension "Responsibility" was considered by seven students as the most important and the second most important and only one student considered less important. The "Guarantee" dimension was considered by three students as the most important, by seven students as the second most important and by four students as the least important. To conclude, the dimension "Empathy" was considered the most important by eight students, two students considered it the second most important and five students regarded it as the least important.

In this way it is observed that there was a variation in the students' responses, a fact that can be analyzed by the cross-distribution between sex and age, since the majority of the students are in the age range between 15 and 19 years, according to Table 6.

Table 6: cross-distribution between size and age group

\begin{tabular}{|c|c|c|c|c|c|c|c|c|c|c|c|c|c|c|c|c|c|c|c|c|c|c|c|c|c|c|}
\hline \multicolumn{10}{|c|}{ Most Important } & \multicolumn{8}{|c|}{ 2nd Most Important } & & \multicolumn{8}{|c|}{ Less Important } \\
\hline \multicolumn{9}{|c|}{ Female audience } & & \multicolumn{8}{|c|}{ Female audience } & \multicolumn{9}{|c|}{ Female audience } \\
\hline & 15 & 16 & 17 & 18 & 19 & 20 & 3 & \begin{tabular}{l|l}
6 & 4 \\
\end{tabular} & & 15 & 16 & 17 & 18 & 19 & 20 & 36 & 4 & & \begin{tabular}{l|l}
5 & 1
\end{tabular} & 16 & 17 & 18 & 19 & 20 & 36 & 45 \\
\hline $\mathbf{A}$ & 0 & 0 & 0 & 0 & 1 & 0 & 0 & 0 & c & 0 & 1 & 0 & 1 & 0 & 0 & 0 & 0 & 2 & 24 & 4 & 0 & 2 & 0 & 0 & 1 & 1 \\
\hline B & 1 & 2 & 0 & 1 & 0 & 0 & 0 & 0 & 1 & 1 & 1 & 0 & 0 & 0 & 0 & 0 & 0 & 1 & 0 & 0 & 0 & 1 & 0 & 0 & 0 & 0 \\
\hline C & 0 & 1 & 0 & 2 & 0 & 0 & 1 & 0 & & 1 & 1 & 0 & 1 & 1 & 0 & 0 & 0 & 1 & 0 & & 0 & 0 & 0 & 0 & 0 & 0 \\
\hline D & 1 & 0 & 0 & 0 & 0 & 0 & 0 & 1 & 2 & 2 & 2 & 0 & 1 & 0 & 0 & 1 & 0 & 0 & 2 & & 0 & 0 & 0 & 0 & 0 & 0 \\
\hline $\mathbf{E}$ & 2 & 3 & 0 & 0 & 0 & 0 & 0 & 0 & c & 0 & 1 & 0 & 0 & 0 & 0 & 0 & 1 & 0 & 0 & & 0 & 0 & 1 & 0 & 0 & 0 \\
\hline \multicolumn{9}{|c|}{ Male audience } & \multicolumn{9}{|c|}{ Male audience } & \multicolumn{9}{|c|}{ Male audience } \\
\hline & 15 & 16 & 17 & 18 & 19 & 20 & 3 & & & 15 & 16 & 17 & 18 & 19 & 20 & 36 & 4 & & \begin{tabular}{l|l}
5 & 1 \\
\end{tabular} & 16 & 17 & 18 & 19 & 20 & 36 & 45 \\
\hline $\mathbf{A}$ & 0 & 0 & 1 & 0 & 0 & 0 & 0 & 0 & & 0 & 0 & 0 & 1 & 0 & 0 & 0 & 0 & 0 & 0 & 0 & 0 & 0 & 0 & 0 & 0 & 0 \\
\hline B & 0 & 0 & 0 & 0 & 0 & 1 & 0 & 0 & 1 & 1 & 0 & 0 & 0 & 0 & 0 & 0 & 0 & 0 & 1 & 1 & 1 & 1 & 0 & 0 & 0 & 0 \\
\hline C & 0 & 0 & 0 & 0 & 0 & 0 & 0 & 0 & & 0 & 1 & 1 & 0 & 0 & 1 & 0 & 0 & 0 & 0 & 0 & 0 & 0 & 0 & 0 & 0 & 0 \\
\hline $\mathbf{D}$ & 0 & 0 & 0 & 1 & 0 & 0 & 0 & 0 & & 0 & 0 & 0 & 0 & 0 & 0 & 0 & 0 & 1 & 0 & 0 & 0 & 0 & 0 & 0 & 0 & 0 \\
\hline $\mathbf{E}$ & 1 & 1 & 0 & 0 & 0 & 0 & 0 & 0 & 0 & 0 & 0 & 0 & 0 & 0 & 0 & 0 & 0 & 0 & 0 & & 0 & 0 & 0 & 1 & 0 & 0 \\
\hline
\end{tabular}

\section{CONCLUSION}

The main characteristics of each of SERVQUAL's five dimensions were presented in the research, with the intention of being a facilitating agent that helps and directs teachers and students involved in the educational process, since it seeks to make a comparison between the expectations and perceptions presented. It should be emphasized that the objective of the research is to broaden the discussion and the theoretical basis surrounding the theme of educational quality.

Evaluating the context, it is important to mention that with the constant evolution of technology, new changes in educational proposals, their behaviors and ways of 
determining the new student-teacher relationship to administer and facilitate educational management activities and processes are remodeled.

In this way, the work contributed to those who seek to better understand the definitions and concepts related to SERVQUAL, thus providing researchers and stakeholders with a study on the subject. As a limitation of this study, it is possible to say that, the study is in the phase of forming an interdisciplinary team to propose solutions to the data presented in this study, which will involve baccalaureate students, integrated technical, concomitant and subsequent.

But as a way to validate students' scores and perceptions regarding the quality of service provided, the students were asked to inform which of the 5 constructs they considered most important and was marked Empathy, the second most important were responsibility and guarantee and the least important was the tangibility of the.

Allowing to observe in a cross-analysis that the tangible construct obtained the third highest score, but was marked as being the least important, the construct guarantee that in the score obtained the lowest score, was marked as the second most important, together with the construct responsibility.

Observing the distribution of points and the choices between the most and least important, there were some cases of inconsistency, because a high score was given and in the classification of importance was not given the same importance. In this group occurs the predominance of women and the majority are young, between 15 and 19 years. Having only two respondents above the age of 30 . Five respondents did not want to report their age as well as genre.

The research is being extended to other classes of technical courses, as a way to improve the validation of research questions, as well as to improve the answers to the research question, which will be made available in future works.

\section{REFERENCES}

ABDULLAH, F. (2006a) The development of HEdPERF: a new measuring instrument of service quality for the higher education sector, International Journal of

Consumer Studies, v. 30, n. 6, p. 569-581. DOI: http://dx.doi.org/10.1111/j.14706431.2005.00480.x

ABDULLAH, F. (2006b) Measuring service quality in higher education: HEdPERF versus SERVPERF, Marketing Intelligence \& Planning, v. 24, n. 1, p. 31-47. DOI: https://doi.org/10.1108/02634500610641543 
ARAÚJO, A. M.; FILHO, J. M. M.; PINTO, R. J.; MACHADO, W. R.B.: SILVA, A.C.G.C. (2017) Análise da qualidade em um restaurante universitário através da ferramenta SERVQUAL. Exacta - EP, São Paulo, v. 15, n. 4, p. 103-115.

BROWNE, B. A.; KALDENBERG, D. O.; BROWNE, W. G.; BROWN, D. J. (1998) Student as customer: Factors affecting satisfaction and assessments of institutional quality, Journal of Marketing for Higher Education, v. 8, n. 3, p. 1-14. DOI: https://doi.org/10.1300/J050v08n03_01

CHUI, T. B.; BIN AHMAD, M. S. (2016) Evaluation of servisse quality of Private Higher education using service improvement matrix. Procedia-Social and Behavioral Sciences, n. 224, p. 132-140. DOI: https://doi.org/10.1016/j.sbspro.2016.05.417

CLEWES, D. (2003) A student-centred conceptual model of servisse quality in higher education, Quality in Higher Education, v. 9, n. 1, p. 69-85.

CUKIER, R.; SILVA, O. R. (2012) Análise dos GAPS da qualidade de serviços medidos pelo modelo servqual em farmácia de manipulação. ENIAC Pesquisa, Guarulhos (SP), v. 1, n. 1, p. 77-91, jan.jun.

DE JAGER, J.; GBADAMOSI, G. (2013) Predicting students' satisfaction through service quality in higher education, The International Journal of Management Education, v. 11, n. 3, p. 107-118.

DETTEMER, B.; SOCORRO, C.; KATON, H. T. (2002) Marketing de ServiçosAnálise da percepção da qualidade de serviços através da ferramenta Servqual em uma instituição de ensino superior de Santa Catarina. Revista de Ciências da Administração, v. 4, n. 08, jul/dez.

GIL, A. C. (2002) Como elaborar projetos de pesquisa. 4 ed. - São Paulo: Atlas. LEONNARD. (2018) The Performance of SERVQUAL to Measure Service Quality in Private University, Journal on Efficiency and Responsibility in Education and Science, v. 11, n. 1, p. 16-21. DOI: 10.7160/eriesj.2018.110103.

LONGO, J. M. R.; VERGUEIRO,W. (2003) Gestão da qualidade em serviços de informação do setor público: características e dificuldades para sua implantação. Revista Digital de Biblioteconomia e Ciência da Informação, Campinas, v. 1, n. 1, p. 39-59, jul/dez. ISSN: 1678-765X.

LOURES, C. A. S.; CAMPOMAR, M. C. (2005) Um estudo sobre o uso da evidência física como forma de gerar percepções de qualidade de serviços: casos de hospitais brasileiros. Revista Brasileira de Gestão e Negócios, São Paulo, v. 7, n. 17, p. 3846, abr.

LOVELOCK, C. (2001) Serviços: marketing e gestão. São Paulo: Saraiva.

MARZO-NAVARRO, M.; PEDRAJA-IGLESIAS, M.; PILAR RIVERA-TORRES, M. (2005) Measuring customer satisfaction in summer courses, Quality Assurance in Education, v. 13, n. 1, p. 53-65. DOI: https://doi.org/10.1108/09684880510578650

MATTAR, F. N. (2000) Pesquisa de marketing. 2. ed. São Paulo: Atlas.

NAIDU, P.; DERANI, N. E. S. (2016) A comparative study on quality of education received by students of private universities versus public universities. Procedia Economics and Finance, v. 35, p. 659-666. 
NORMANN. R. (1993) Administração de Serviços: estratégia e liderança na empresa de serviços. São Paulo: Atlas.

OLDFIELD, B. M.; BARON, S. (2000) Student perceptions of service quality in a UK university business and management faculty, Quality Assurance in education, $v$. 8, n. 2, p. 85-95.

PARASURAMAN, A.; ZEITHAML, V. A.; BERRY, L. L. (1988) Servqual: A multipleitem scale for measuring consumer perception of service quality, Journal of retailing, v. 64, n. 1, p. 12.

ROSEMBERG, D. S.; MIGUEL, M. C.; DE CARVALHO, S. M. S. (2018) QUALIDADE PERCEBIDA NA ÓTICA DO USUÁRIO: emprego da abordagem teórico-metodológica servqual em um serviço de referência. PontodeAcesso, v. 12, n. 2, p. 40-57.

ROSS, J. M., SHARAPOV, D. (2015) When the leader follows: avoiding dethronement through imitation. Academy of Management Journal, v. 58, n. 3, p. 658-679.

SMITH, W. K.; TRACEY, P. (2016) Institutional complexity and paradox theory: Complementarities of competing demands. Strategic Organization, v. 14, n. 4, p. 455-466.

ZAMMUTO, R. F.; KEAVENEY, S. M.; O'CONNOR, E. J. (1996) Rethinking student services: assessing and improving servisse quality, Journal of Marketing for Higher Education, v. 7, n. 1, p. 45-70. DOI: https://doi.org/10.1300/J050v07n01_05. WAGNER, A.; MERINO, E. A. D.; MARTINELLI, M.; POLACINSKI, É.; DA SILVA WEGNER, R.; GODOY, L. P. (2018). The quality of services in a higher education institution: an evaluation for the integration of AHP, SERVQUAI and QFD methods. Disciplinarum Scientia| Sociais Aplicadas, v. 13, n. 1, p. 109-130. 